\title{
FORUM FOR MARKEDSFØRING
}

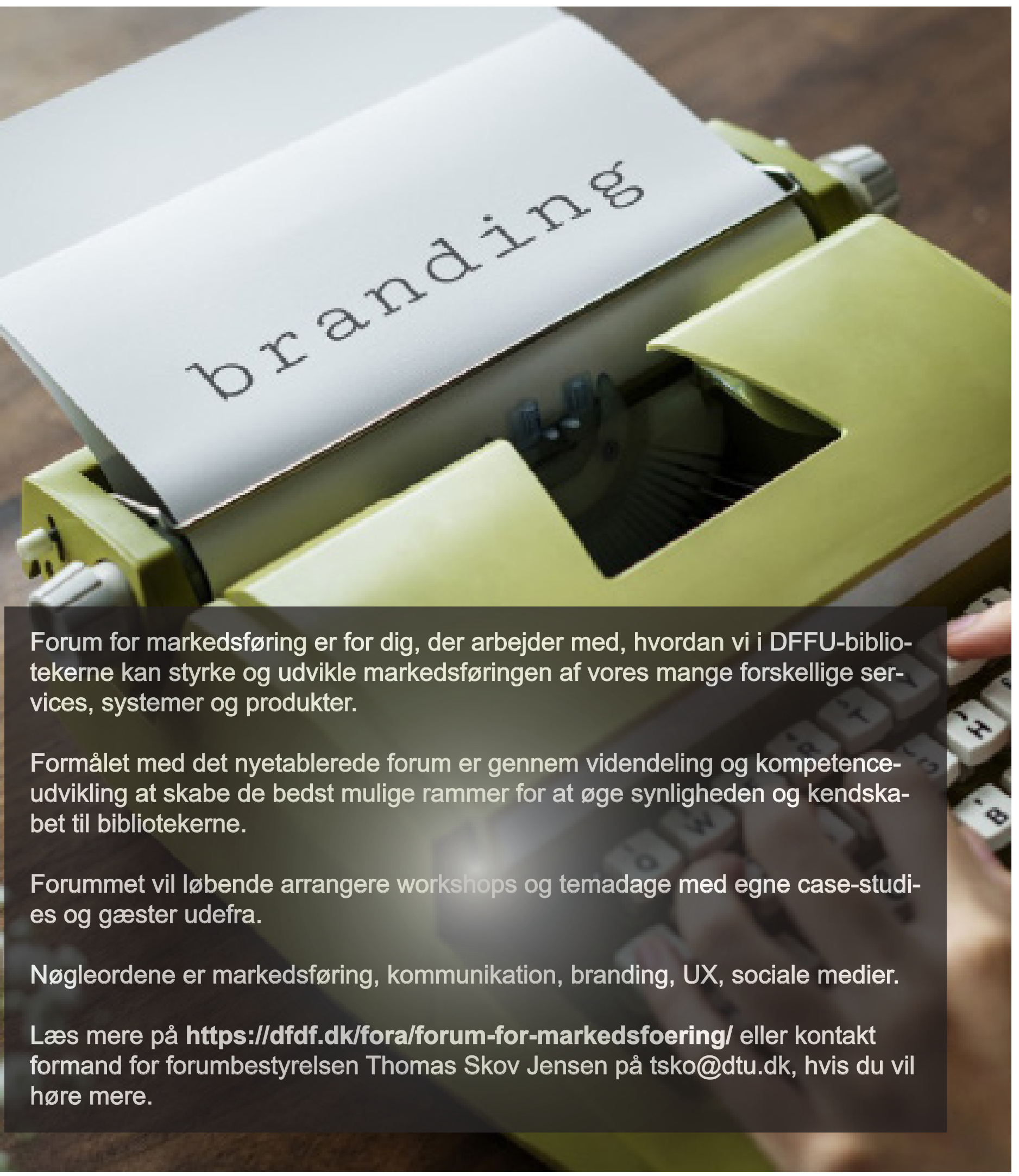

